\title{
ИНФОРМАЦИОННЫЙ ПОДХОД В ФОРМИРОВАНИИ БИЛИНГВАЛЬНОЙ КОММУНИКАТИВНОЙ КОМПЕТЕНЦИИ СТУДЕНТОВ МЕДИЦИНСКОГО НАПРАВЛЕНИЯ ПОДГОТОВКИ
}

\section{INFORMATION APPROACH IN FORMING OF BILINGUAL COMMUNICATIVE COMPETENCE IN MEDICAL STUDENTS \\ T. Tsarskaya \\ L. Kushnyr \\ Yu. Dyachenko}

Summary: The authors consider the significance of the formation of bilingual communicative competence in medical students in the context of the information approach, and substantiate its methodological significance. The need to update the problem of applying the information approach in the formation of bilingual communicative competence is due to improve the quality of training of a competent specialist in the field of medicine who knows modern communication technologies, including in a foreign language(s) for academic and professional interaction and is able to apply information technologies in professional activities.

Keywords: information approach, medical students, bilingual communicative competence.
Царская Татьяна Сергеевна

Преподаватель, Сургутский государственный университет Кушнырь Любовь Александровна Старший преподаватель, Сургутский государственный университет lak2001@yandex.ru

Дьяченко Юлия Васильевна К.филол.н., старший преподаватель, Сургутский государственный университет julia2212@yandex.com

Аннотация: Авторы работы рассматривают значимость формирования билингвальной коммуникативной компетенции студентов медицинского направления подготовки в условиях информационного подхода, обосновывается его методологическая значимость. Необходимость актуализации проблемы применения информационного подхода в формировании билингвальной коммуникативной компетенции обусловлена потребностью в совершенствовании качества подготовки компетентного специалиста в области медицины, владеющим современными коммуникативными технологиями, В том числе на иностранном(ых) языке(ах) для академического и профессионального взаимодействия и способного применять информационные технологии в профессиональной деятельности.

Ключевые слова: информационный подход, студенты медицинского направления подготовки, билингвальная коммуникативная компетенция.

дицинской сферы определяется комплексом сформированных компетенций к концу их обучения.

Профессиональная, научно-исследовательская, коммуникативная, информационная компетенции, которые в современном ФГОС ВО заложены в планируемые результаты обучения студентов медицинского вуза, все больше сосредотачивают внимание преподавателей на их адекватное формирование и совершенствование [7, с. 231].

Федеральный государственный образовательный стандарт высшего образования при реализации программы специалитета медицинского направления подготовки требует следующие сформированные у выпускника компетенции: универсальная компетенция (УК-4) - способен применять современные коммуникативные технологии, в том числе на иностранном(ых) языке(ах) для академического и профессионального взаимодействия; (УК-5) - способен анализировать и учитывать разнообразие культур в процессе межкультурного взаимодействия; общепрофессиональная компетенция (ОПК-12) - способен применять информационные техно- 
логии в профессиональной деятельности [6].

Отсюда следует, что развитие иноязычных коммуникативных умений и навыков студентов медицинского направления подготовки для академического и профессионального взаимодействия, их способности анализировать и учитывать разнообразие культур в процессе межкультурного взаимодействия, а также применение информационных технологии для качественной обработке, анализа и синтеза информационного потока на государственном и иностранном языках в процессе обучения с соблюдением правил информационной безопасности обуславливает актуализацию информационного подхода в проблеме формирования билингвальной коммуникативной компетенции (далееБКК) студентов медицинского направления подготовки для реализации их профессионального становления, как специалиста.

Формирование БКК студентов медицинского направления подготовки рассматривается в контексте обучения иностранному языку, основной целью которого уже больше не является только обучение иноязычной коммуникативной компетенции по аспектным разделами «фонетика», «грамматика», «лексика», «аудирование». Роль дисциплины иностранный язык оказывается значительно шире этой единственной цели [9, с. 293].

Как отмечает С.Н. Барышникова, развитие и совершенствование иноязычной коммуникативной компетенции студентов медицинского вуза обусловлено появлением новых носителей международной информации, способов ее переработки, оптимизацией по экономическим и энергетическим показателям соотношения между отечественными и иностранными информационными потоками [1].

Следовательно, назревает необходимость оптимизировать изрядный информационный отечественный и зарубежный поток медицинского характера в процессе подготовки специалистов медицинского вуза посредством применения двух, а то и трех языков, с использованием информационно-коммуникационных технологий для ее восприятия, обработки, трансформации, при этом, актуализируется и методологическая значимость информационного подхода в его освоении.

Для определения методологической значимости информационного подхода в рамках проблемы формирования БКК студентов медицинского направления подготовки необходимо обратиться к вопросу рассмотрения самого понятия «информационный подход», определить его сущность и значимость, определить формы, методы его применения.

Впервые, на значимость информационного подхода в производственно-коммуникативной деятельности человека обратили внимание Н. Винер и У.Р. Эшби. Принимая во внимание определение информации, как «сведения об окружающем мире, протекающих в нем процессах, воспринимаемые человеком или специальным устройством», или же «любые сведения и данные, являющиеся объектом передачи, хранения и переработки» [4, с.4], в своей работе «Человек управляющий» Н. Винер показал, что понимание информации обществом возможно на пути исследования как сигналов и средств ее связи, так и развития обмена информацией между человеком и машиной, между машиной и человеком, между машиной и машиной. Н. Винер считал, что любая система в производственно-коммуникативной деятельности человека работает эффективно, когда она получает информацию о состоянии этой системы и на основе ее модернизирует свои управляющие сигналы [2].

То есть, любая информация имеет обратную связь и этой связью можно и следует управлять и контролировать с применением вербально-логических и математических средств.

Разработанная на математической теории информации модель коммуникации Н. Винера состоит из: источник (информации) - сообщение (передающееся через канал восприятия) - получатель - обратная связь (получателя и источника информации). В своей коммуникационной модели Н. Винер добавляет обратную связь ответная реакция получателя на сообщение источника, механизм которой позволяет в процессе коммуникации сделать информацию не односторонней, направленной в одну сторону, а двухсторонней, управляемой и контролируемой [2].

Преобразованные концептуальные взгляды Н. Винера и У.Р. Эшби к проблемам образования находят свое отражения в работах В.Б. Гухмана, В.Я. Цветкова, Н.И. Пака.

Пак Н.И. в своей работе «О концепции информационного подхода в обучении» отмечает, что информационная природа познания позволяет говорить об информационном подходе к проектированию и диагностике образовательных систем, процесса обучения. Он отмечает, что информационный подход в образовании следует формировать на базе информационных постулатов, методе информационного моделирования сущности, развитии знаний обучающегося через механизм восприятия и извлечения информации из естественных и искусственных сообщений [5, с. 91].

При этом в практической деятельности человек использует содержательную информацию или знания. Таким образом, первым шагом информационного подхода является сбор информации и выделение из нее содержательной информации или знаний [8, с. 645]. 
В обучении иностранного языка применение информационного подхода на разных образовательных ступенях рассматривался такими учеными: Э.Г. Азимов, А.Н. Багрова, Е.И. Дмитриева, Д.Д. Климентьев, Т.В. Кожевникова, Г.А. Комиссарова, О.П. Крюкова, А.Л. Назаренко, Э.Л. Носенко, И.П. Павлова, М.Б. Петрова, А.А. Петухова, Е.С. Полат, И.Л. Сергиевская, С.В. Титова, М. Г. Евдокимовой, И.А. Смольянникова, С.А. Фомин, G.D. Davies, J. Higgins, T. Johns, Ch. Jones, S. Fortescue, M.J. Kenning, M.-M. Kenning, M. Levy.

С одной стороны основной задачей исследователей заключалась в проблеме обоснования информационного подхода и поиска интеграционных путей, методов внедрения информационно-коммуникационных технологий в процесс обучения иностранному языку на разных ступенях образования.

Другая задача и значимость применения информационного подхода в процессе обучения иностранному языку можно выразить словами Цветков В.Я., «...информационный подход существенен и обеспечивает преемственность между ручными, автоматизированными и интеллектуальными методами исследования. Он создает возможности совершенствования методов исследования и накопления информационного опыта исследования зафиксированного в объективных, независимых от человека моделях и описания. Главное преимущество информационного подхода в том, что он создает возможности междисциплинарного переноса опыта исследований и логико-математических методов» [8, с. 645].

Существуют работы, посвященные вопросам интеграции концептуальных положений современной теории высшего профессионального образования и теории образования в области лингвистики в единой системе обучения иностранному языку на основе информационного подхода с реализацией дидактического потенциала информационно-коммуникационных технологий. Так, в 2007 году М.Г. Евдокимовой обоснована методология использования новейших информационно-коммуникационных технологий для создания системы обучения иностранным языкам в техническом вузе, интегрирующие концептуальные положения современной лингводидактики, методики обучения иностранному языку и смежных с ними наук [3].

Концептуальные взгляды Н. Винера и У.Р. Эшби, анализ научных работ по проблемам применения информатизации к образовательной среде, в том числе к обучению иностранного языка на разных ступенях, позволяет нам обозначить ведущие функции информационного подхода, как методологической составляющей к вопросу формирования БКК студентов медицинского направления подготовки:

1. обеспечение дисциплины «Иностранный язык» информационно-коммуникационными инструментариями для профессиональной подготовки студентов медицинского направления;

2. расширение использование средств информационно-коммуникационных технологий, способствующие расширенному изучению и усвоению иностранному языку;

3. моделирование содержания дисциплины качественно новых целей обучения в направлении подготовки членов будущего «информационного общества», для которого способность к человеческим коммуникациям, активное овладение билингвальной, информационной коммуникацией для понимания и восприятия межкультурной и научной картины мира, гибкого изменения своих функций в будущем профессиональном труде и творческого мышления;

4. возможность совершенствования методов исследования БКК и накопления информационного опыта исследования зафиксированного в объективных, независимых от человека моделях и описания; междисциплинарного переноса опыта исследований и логико-математических методов. Как правильно подметил Н.И. Пак «информационный подход облегчает формализацию понятийного аппарата, упорядочивает информационную картину мира, дополняет дидактику информационными процессами обучения, а методы дидактики вооружает информационными методами [5, с. 97].

\section{Выводы}

На основе изученного нами материала по вопросу рассмотрения информационного подхода в проблеме формирования БКК студентов медицинского направления подготовки можно резюмировать следующие положения:

1. информационный подход не вступает в противоречие с компетентностным, коммуникативно,личностно,- профессионально-ориентированным, деятельностным подходами в формировании БКК студентов медицинского направления подготовки. Как изъясняется Н.И. Пак, «все подходы эквивалентны по отношению к процессам и результатам обучения в силу информационной природы познания и обучения. В каждой конкретной ситуации более разумно использовать тот или иной подход» [5, с. 97];

2. информационный подход обладает интегрирующей функцией в процессе формирования билингвальной коммуникативной компетенции студентов медицинского направления подготовки, обеспечивающая систематизацию знаний в информационной среде, дает возможность предвосхитить, предвидеть результаты ее формирования;

3. информационный подход является методом формирования БКК студентов медицинского направ- 
ления подготовки и способом ее организации который дает возможность увеличить пропускную способность непосредственного канала восприятия информации, ее анализа, переработки, рефлексии;

4. реализация информационного подхода в формировании БКК студентов в медицинском вузе обуславливается применением и варьированием различных средств содержания образования, коммуникационно-информационных технологий, сопровождается созданием условий и ситуаций выполнения их действий для развития академического, межкультурного и профессионального взаимодействия.

\section{ЛИТЕРАТУРА}

1. Барышникова С.Н. Формирование коммуникативной компетенции в системе обучения иноязычной речевой деятельности студентов медицинских вузов: автореферат кандидата педагогических наук. - Саратов, 2005. - 28 с. [Электронный ресурс]/ С.Н. Барышникова. - 2005.

2. Гухман В.Б. Философская сущность информационного подхода: диссертация доктора философских наук. - МГУ, 2001. - 402 с. [Электронный ресурс]/ В. Б. Гухман. - 2001. - Режим доступа: http://libed.ru/knigi-nauka/502621-1-filosofskaya-suschnost-informacionnogo-podhoda.php

3. Евдокимова М.Г. Система обучения иностранным языкам на основе информационно-коммуникационной технологии: технический вуз, английский язык: диссертация доктора педагогических наук. - М., 2007. - 671 с. [Электронный ресурс]/ М.Г. Евдокимова. - 2007. - Режим доступа:https://www.dissercat. com/content/sistema-obucheniya-inostrannym-azykam-na-osnove-informatsionno-kommunikatsionnoi-tekhnologi

4. Ковалевская Е.В. Построение проблемно-информационной модели современного образования // Проблемно-информационный подход к реализации целей современного образования: вопросы теории и практики: Материалы XI международной научно-практической конференции «0бразование на грани тысячелетий» (г. Нижневартовск, 5 ноября 2015 года) / Отв. ред. Л.И. Колесник. — Нижневартовск: Изд-во Нижневарт. гос. ун-та, 2016. — 306 с. - С.3-5.

5. Пак Н.И. О концепции информационного подхода в обучении // Педагогика [Электронный ресурс] /Н.И. Пак. - 2010. -С. 91-97. - Режим доступа: httрs:// cyberleninka.ru/article/n/o-kontseptsii-informatsionnogo-podhoda-v-obuchenii

6. Федеральный государственный образовательный стандарт высшего образования. [Электронный ресурс]. - Режим доступа: http://fgosvo.ru/uploadfiles/ ProjFGOSV03++/Spec3++/320501_3plus_23052017

7. ЦЦарская Т.С., Кушнырь Л.А., Ситникова А.Ю. Методологическая основа модели формирования билингвальной коммуникативной компетенции студентов медицинского и биологического направления подготовки // Педагогический журнал. 2019. Т. 9. № 3-1. С. 230-244.

8. Цветков В.Я. Информационный подход // Международный журнал прикладных и фундаментальных исследований. [Электронный ресурс] - 2016. № 4-3. - С. 645-645. - Режим доступа: https://applied-research.ru/ru/article/view?id=9038

9. Шукурова И.В., Царская Т.С. Развитие общекультурных компетенций студентов неязыковых направлений на примере экстенсивного чтения В сборнике: Сборник избранных статей по материалам научных конференций ГНИИ «Нацразвитие». Материалы конференций. 2019. С. 291-295.

( Ц Царская Татьяна Сергеевна, Кушнырь Любовь Александровна (lak2001@yandex.ru), Дьяченко Юлия Васильевна (julia2212@yandex.com).

Журнал «Современная наука: актуальные проблемы теории и практики» 